\title{
Implementasi Spasial Kriging Dengan Faktor Dependency Seasonal Time Series
}

\author{
Aniq A Rohmawati \\ \#Program Studi Ilmu Komputasi, Telkom University \\ Jalan Telekomunikasi 1, Bandung 40257, Indonesia \\ aniqatiqi@telkomuniversity.ac.id
}

\begin{abstract}
Time series analysis has been developed in concepts and theories to accommodate the behavior of the collected data by involving time. The unique feature of time series analysis is the time dependency. In this research, we observed a number of seasonal pets, fire caterpillars, on an oil palm plantation at Block Afdeling-D in Kalimantan. The number of Fire Caterpillars is dependent on time and spatial (location). Fire Caterpillars are seasonal pests on oil palm plantation. In addition, Pearson correlation indicates that the number of Fire Caterpillars is not influenced by the distance among the blocks. We suggests that the disinfection should be done simultaneously to avoid the migration of fire caterpillars. The spreading of fire caterpillars at Block Afdeling-D in Kalimantan is modeled with time series seasonal model, spesifically with ARIMA homoscedastic model. Kriging interpolation was conducted to identify behavior and determine the location Fire Caterpillars involving ARIMA model.
\end{abstract}

Keywords: ARIMA, dependency, Kriging, Fire Caterpillars, variogram

Abstrak

Analisis time series menjadi kajian yang kian berkembang secara konsep dan teori, untuk mengakomodir perilaku observasi yang dikumpulkan dengan melibatkan waktu. Karakteristik observasi time series terletak pada dependency terhadap waktu. Hama Ulat Api memiliki dependency terhadap waktu dan spasial (lokasi). Ulat Api merupakan hama musiman pada kebun kelapa sawit. Korelasi Pearson menunjukkan jumlah ulat api tidak dipengaruhi oleh jarak antar blok, sehingga pembasmian hama ini harus dilakukan serentak untuk menghindari migrasi ulat api. Model sebaran jumlah ulat api pada Blok Afdeling-D dilakukan dengan model time series seasonal homoskedastik ARIMA. Interpolasi Kriging dilakukan untuk mengetahui perilaku sebaran, interpolasi lokasi dengan berdasarkan hasil forecasting ARIMA.

Kata Kunci: ARIMA, dependency, Kriging, Ulat Api, variogram

\section{PENDAHULUAN}

Ulat api merupakan salah satu komoditas hama perkebunan kelapa sawit. Serangan pertama ulat yang dikenal dengan Nettle Caterpillar ini menurunkan $70 \%$ produksi kelapa sawit dan 93\% pada serangan kedua. Ulat Api memiliki banyak jenis yang merugikan budidaya perkebunan kelapa sawit, yang paling umum antara lain Darna Trima Mr, Setothosea Asigna Mr, dan Setora Nitens Wlk. 
ANIQ ATIQI

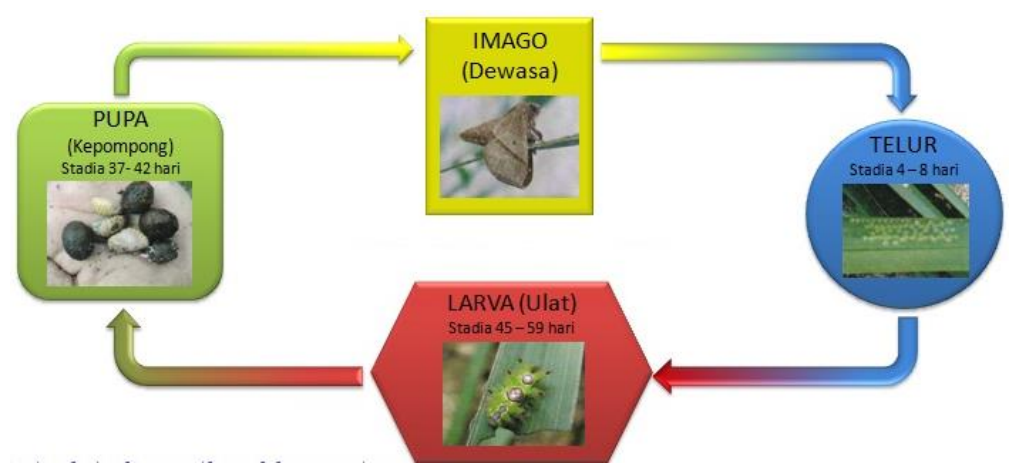

GAMBAR 1. SIKLUS ULAT API [1]

Berdasarkan siklus Gambar 1, Ulat Api Darna, larva muda instar 1 memakan jaringan epidermis bagian bawah daun hingga nekrosis. Pada instar 2, memakan daun hingga habis dan menyisakan tulang daun saja, 30 ulat per pelepah daun muda dan 60 ulat per pelepah daun tua. Pada ulat api Asigna, larva instar 1 memiliki perilaku yang sama dengan jenis Darna. Pada instar 4, larva mengisolasi diri, memakan semua bagian daun hingga jumlah besar, 4-5 helai daun dan menyebar pada pelepah daun ke 9-25. Pada ulat api Nitens, memiliki kemiripan perilaku seperti jenis Asigna [1]. Data geografis agregat didasarkan pada berbagai kuantitas dan spasial yang berubah-ubah, sebagai akibatnya, perlu diperhitungkan karakteristik statistik data [8].

Analisis time series menjadi kajian yang kian berkembang secara konsep dan teori, terutama untuk mengakomodir perilaku data observasi yang dikumpulkan dengan melibatkan waktu. Konsep utama identifikasi observasi time series terletak pada dependency terhadap waktu. Tujuan utama analisis time series adalah memodelkan mekanisme stokastik dari obervasi yang dikumpulkan berdasarkan runtun waktu untuk memprediksi nilai di masa depan berdasarkan observasi-observasi sebelumnya. Model Kriging banyak diterapkan dan dikembangkan pada bidang statistika spasial dan geostatistik. Kriging memprediksi nilai dengan melakukan intepolasi pada lokasi yang tidak diketahui. Interpolasi Kriging melibatkan proses stokastik yang didasarkan pada observasi lokasi- lokasi disekitarnya. Lokasi observasi disebut sebagai sampel titik yang selanjutnya dilakukan interpolasi dengan fungsi acak Gaussian untuk mengestimasi tren proses stokastik yang melekat pada data observasi [2].

Zhou (2006) menggunakan spasial time series untuk memodelkan harga kayu di negara Amerika bagian selatan, dengan mepertimbangkan dependency (kebergantungan) harga di setiap daerah pada interval waktu tertentu [6]. Permasalahan komputasi muncul ketika cross product pasangan data yang melibatkan spasial dan time series menghasilkan nilai dependency tinggi yang tidak dapat diabaikan. Grouping lokasi dengan Kriging menjadi alternatif yang dilakukan oleh Zhang (2003) untuk pasangan data spasial [7]. Namun, dependency time series seringkali diabaikan, sehingga pada penelitian ini melibatkan model time series ARIMA untuk mendukung model spasial dari observasi.

Analisis geostatistik dan pemodelan sebaran Ulat Api perkebunan kelapa sawit Blok Afdeling-D Kalimantan dilakukan dengan dua tahap, yaitu forecasting dengan model time series dan interpolasi lokasi dengan Kriging. Anlisis pemodelan time series terdiri dari tiga tahap, yaitu identifikasi model, penaksiran parameter, dan uji mean error. Lebih lanjut, identifikasi perilaku data dilakukan dengan mengetahui besar ukuran dependency dari sampel observasi, sehingga diperoleh model time series. Selanjutnya, pemodelan Kriging dilakukan dengan menentukan model semivariogram, menaksir parameter, dan menentukan sebaran titik interpolasi. 


\section{FORECASTING MODEL ARIMA SEBARAN JUMLAH ULAT API}

Data yang digunakan adalah data jumlah ulat api setiap blok pada Blok Afdeling-D di Kalimantan. Blok Afdeling D terdiri atas 30 blok yang saling berdekatan. Observasi dilakukan setiap bulan pada periode Januari 2011 - Desember 2013. Ulat api yang diamati adalah ulat sehat, pada masing - masing blok pada Blok AfdelingD telah dipilih beberapa titik sampel observasi. Pemilihan titik sampel berdasarkan lokasi dan keberpengaruhan titik sampel terhadap sampel lainnya.

Berdasarkan grafik Gambar 3, jumlah ulat api masing - masing Blok Afdeling D menunjukkan perilaku seasonal, yaitu siklus kenaikan dan penurunan pada periode yang sama. Kenaikan serangan Ulat Api terbesar selama kurun waktu 3 tahun terjadi pada tahun 2012. Berikut ini merupakan siklus intensitas kemunculan ulat api yang diperoleh berdasarkan pengamatan selama 3 tahun,

1. Serangan ulat api mulai muncul pada bulan Juni setiap tahun

2. Intensitas serangan mengalami penurunan pada bulan Juli setiap tahunnya

3. Serangan ulat api kedua muncul pada bulan Agustus dengan jumlah yang lebih besar dari serangan pertama

4. Setelah bulan Agustus, jumlah ulat api berangsur-angsur mengalami penurunan dan klimaks penurunannya terjadi pada bulan Desember
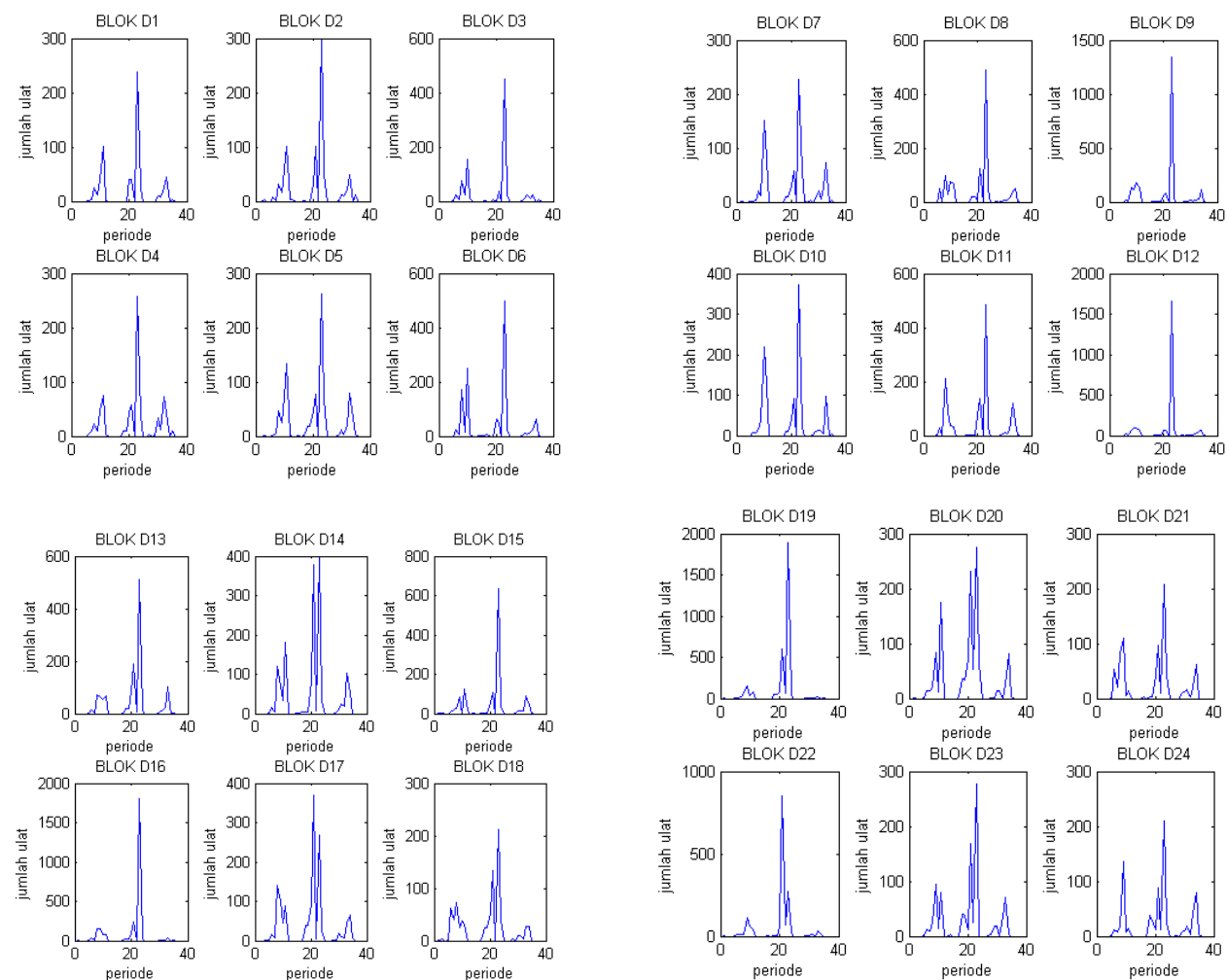

GAMBAR 3. SAMPEL SEASONAL TREND JUMLAH ULAT API BLOK AFDELING-D

Berdasarkan Gambar 3, menjadi hal yang menarik untuk mengetahui besarnya keberpengaruhan (dependency) jumlah ulat diantara blok - blok tersebut, baik blok yang berdekatan maupun yang berjauhan. Untuk blok yang berdekatan, diperoleh nilai korelasi Pearson, $\rho=0.94$. Sedangkan, untuk blok berjauhan diperoleh $\rho=0.78$. Hal 
ANIQ ATIQI

IMPLEMENTASi SPASIAL Kriging DENGAN FAKTOR...

ini menunjukkan apabila terjadi serangan ulat api, maka serangan tersebut akan menyebar keseluruh blok AfdelingD.

Sebaran jumlah Ulat Api erat hubungannya dengan periode atau waktu. Sebelum melakukan interpolasi spasial sebaran Ulat Api, terlebih dahulu dilakukan forecasting dengan model time series. Pada grafik Gambar 3, sebaran jumlah Ulat Api menunjukkan tren ketidakstasioneran, dengan mean dan variansi yang cenderung berubah terhadap waktu. Detrend dilakukan dengan differencing(1) pada data observasi, untuk mendapatkan tren stasioner. Model homoskedastik merupakan model time series dengan standar deviasi bersyarat (volatilitas) yang cenderung tidak berubah terhadap waktu. Sebaliknya, dinamakan model heteroskedastik. Gambar 4 menunjukkan sebaran jumlah ulat api Blok Afdeling-D memiliki kebergantungan kuat antara observasi hari ini $(t)$ dengan sebelumnya $(t-1)$, dengan interval nilai $\rho$ antara 0.78 sampai 0.96 , dengan mempertimbangkan nilai tersebut, maka sebaran Ulat Api dapat dimodelkan dengan model time series Autoregressive.
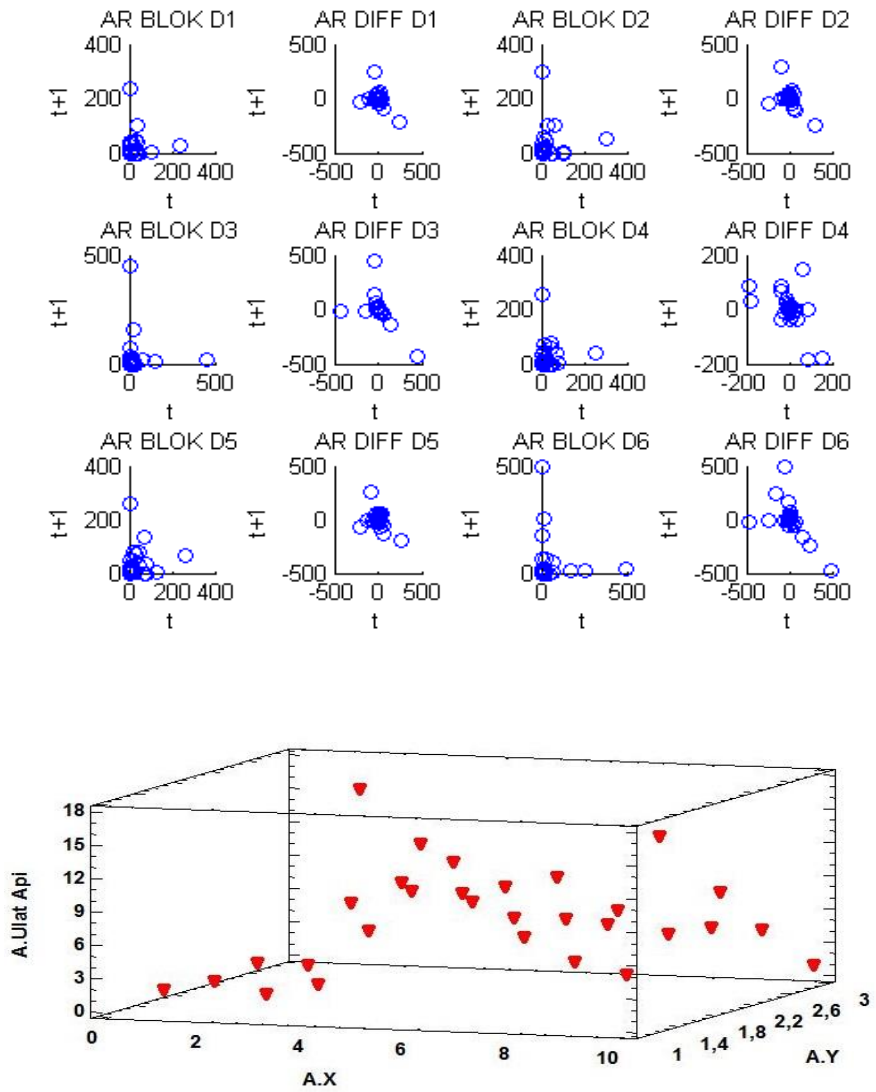

GAMBAR 4. SCATTERPLOT DEPENDENCY WAKTU DAN SPASIAL BLOK AFDELING-D

Tujuan utama analisis geostatistik adalah melakukan interpolasi nilai berdasarkan kebergantungan (dependency) spasial. Tanpa adanya kebergantungan maka tidak memungkinkan untuk melakukan interpolasi titik diantara lokasi-lokasi observasi tersebut [5]. Grafik pada Gambar 4 menunjukkan pola kebergantungan waktu dan spasial dari data Ulat Api. Selain itu, data observasi memiliki kebergantungan kuat dengan karakteristik observasi yang menggerombol dengan pola tertentu.

Misalkan $Y_{t}$ adalah peubah acak yang menyatakan banyaknya Ulat Api pada saat $t$, maka Model heteroskedastik ARCH (Autoregressive Conditional Heteroskedastik) didefinisikan sebagai [3], 


$$
\mathrm{Y}_{t}=\sigma_{t} e_{t}, \quad \sigma_{t}^{2}=\alpha_{0}+\alpha_{1} Y_{t-1}
$$

$\alpha_{0}>0, \alpha_{1} \geq 0$ dengan

1. $\left\{\varepsilon_{\mathrm{t}}\right\}$ merupakan barisan peubah acak saling bebas dan berdistribusi identik $N \sim\left(0, \sigma^{2}\right)$

2. $\sigma_{\mathrm{t}}$ dan $\varepsilon_{\mathrm{t}}$ saling bebas, $\mathrm{Y}_{\mathrm{t}-1}$ dan $\varepsilon_{\mathrm{t}}$ saling bebas

3. $\mathrm{Y}_{\mathrm{t}}$ dan $\mathrm{Y}_{\mathrm{t}-1}$ tidak saling bebas, $\mathrm{Y}_{\mathrm{t}}$ dan $\varepsilon_{\mathrm{t}}$ tidak saling bebas

Berikut ini merupakan selisih data prediksi model heteroskedastik $\mathrm{ARCH}(1)$ dengan data observasi,
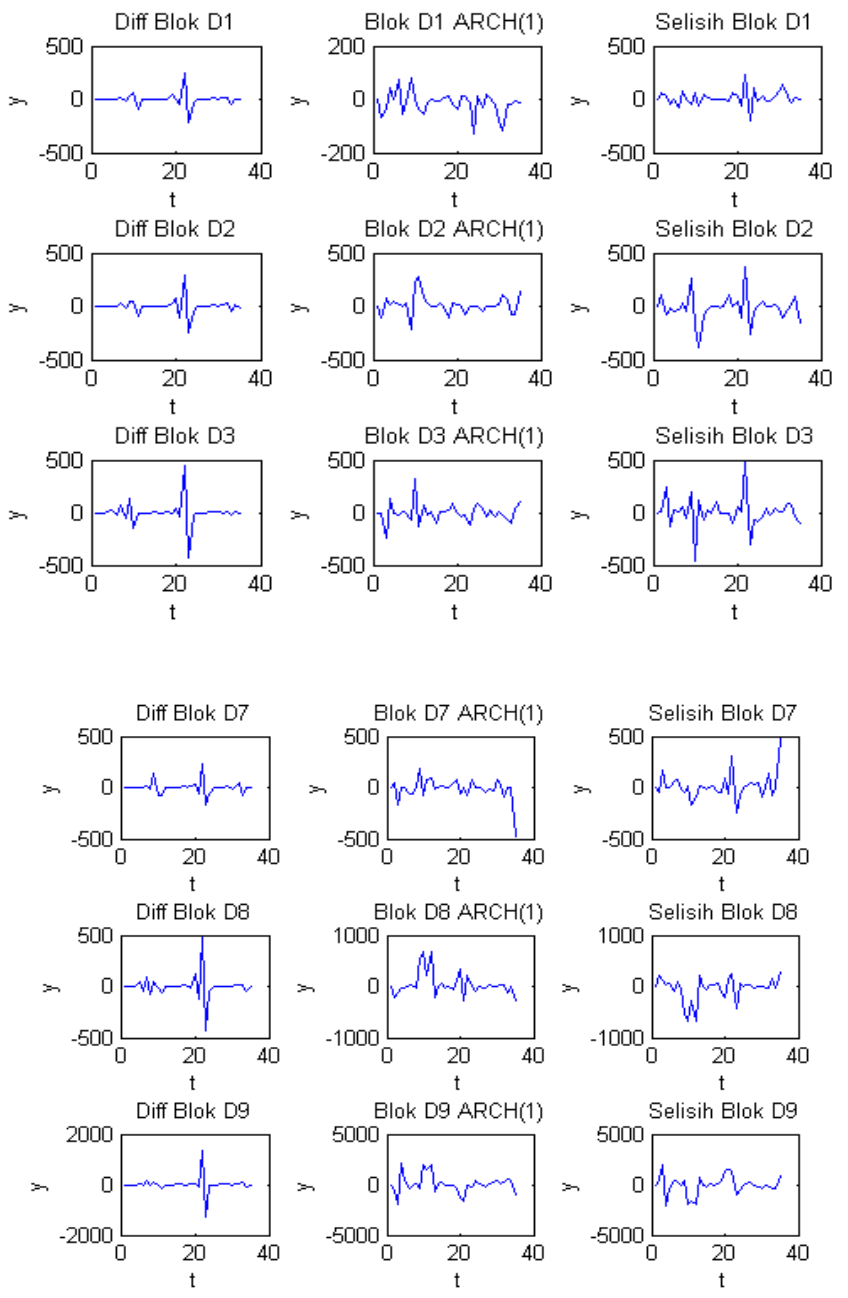

GAMBAR 5. PLOT SELISIH ARCH(1) DAN OBSERVASI DENGAN DIFFERENCING (1)

Berdasarkan grafik Gambar.5, sebaran ulat api pada Blok Afdeling-D tidak sesuai dimodelkan dengan model ARCH(1), karena hasil prediksinya memiliki selisih yang besar terhadap data observasi. Oleh karena itu, dengan mempertimbangkan analisis pada Gambar 4 dan proses differencing (1) yang dilakukan, maka pemodelan sebaran ulat api dilakukan dengan model homoskedastik ARIMA (Autoregressive Integrated Moving Average). Himpunan peubah acak $\left\{Y_{t}\right\}$ dikatakan mengikuti model Model Autoreressive Integrated Moving Average, ARIMA (p,d,q), jika model tersebut melibatkan proses ARMA $(\mathrm{p}, \mathrm{q})$ dan differencing ke- $d$. Orde $p$ merupakan orde Autoregressive dan $q$ untuk orde Moving Average, $d$ merupakan proses differencing. Dapat ditulis model ARIMA (p,1,q) sebagai berikut [3], 
ANIQ ATIQI

IMPLEMENTASI SPASIAL KRIGING DENGAN FAKTOR...

$$
W_{t}=\alpha_{1} W_{t-1}+\alpha_{2} W_{t-2}+\cdots+\alpha_{p} W_{t-p}+e_{t}-\theta_{1} e_{t-1}-\theta_{2} e_{t-2}-\cdots-\theta_{q} e_{t-q}
$$

dengan $W_{t}=Y_{t}-Y_{t-1}$. Mempertimbangkan plot ACF (Autocorrelation Function) - PACF (Partial Autocorrelation Function) masing - masing blok, maka diperoleh model ARIMA dan hasil forecasting jumlah ulat api (bulan Januari dan Februari 2014) masing - masing blok pada Tabel 1 sebagai berikut,

TABEL 1. HASIL FORECASTING SEBARAN ULAT API DENGAN ARIMA

\begin{tabular}{|c|c|c|c|c|}
\hline Blok & ARIMA & Parameter Model & Forecasting 1 & Forecasting 2 \\
\hline D1 & $(1,1,1)$ & $\mathrm{Y}_{\mathrm{t}}=-0.170-0.440 \mathrm{Y}_{\mathrm{t}-1}+0.988 \varepsilon_{\mathrm{t}-1}+\varepsilon_{\mathrm{t}}$ & 0 & 0 \\
\hline D2 & $(1,1,1)$ & $\mathrm{Y}_{\mathrm{t}}=-0.219-0.499 \mathrm{Y}_{\mathrm{t}-1}+0.955 \varepsilon_{\mathrm{t}-1}+\varepsilon_{\mathrm{t}}$ & 0 & 0 \\
\hline D3 & $(1,1,1)$ & $\mathrm{Y}_{\mathrm{t}}=-0.255-0.482 \mathrm{Y}_{\mathrm{t}-1}+0.996 \varepsilon_{\mathrm{t}-1}+\varepsilon_{\mathrm{t}}$ & 0 & 0 \\
\hline D4 & $(2,1,1)$ & $\mathrm{Y}_{\mathrm{t}}=-0.204-0.587 \mathrm{Y}_{\mathrm{t}-1}-0.251 \mathrm{Y}_{\mathrm{t}-2}+0.995 \varepsilon_{\mathrm{t}-1}+\varepsilon_{\mathrm{t}}$ & 0 & 0 \\
\hline D5 & $(1,1,1)$ & $\mathrm{Y}_{\mathrm{t}}=-0.255-0.393 \mathrm{Y}_{\mathrm{t}-1}+0.989 \varepsilon_{\mathrm{t}-1}+\varepsilon_{\mathrm{t}}$ & 0 & 0 \\
\hline D6 & $(1,1,1)$ & $\mathrm{Y}_{\mathrm{t}}=-0.359-0.529 \mathrm{Y}_{\mathrm{t}-1}+0.990 \varepsilon_{\mathrm{t}-1}+\varepsilon_{\mathrm{t}}$ & 0 & 1 \\
\hline D7 & $(1,1,1)$ & $\mathrm{Y}_{\mathrm{t}}=-0.216-0.356 \mathrm{Y}_{\mathrm{t}-1}+0.987 \varepsilon_{\mathrm{t}-1}+\varepsilon_{\mathrm{t}}$ & 1 & 1 \\
\hline D8 & $(1,1,1)$ & $\mathrm{Y}_{\mathrm{t}}=-0.325-0.536 \mathrm{Y}_{\mathrm{t}-1}+0.999 \varepsilon_{\mathrm{t}-1}+\varepsilon_{\mathrm{t}}$ & 0 & 1 \\
\hline D9 & $(1,1,1)$ & $Y_{t}=-0.663-0.460 Y_{t-1}+0.983 \varepsilon_{t-1}+\varepsilon_{t}$ & 1 & 0 \\
\hline D10 & $(1,1,1)$ & $\mathrm{Y}_{\mathrm{t}}=-0.368-0.507 \mathrm{Y}_{\mathrm{t}-1}+0.985 \varepsilon_{\mathrm{t}-1}+\varepsilon_{\mathrm{t}}$ & 0 & 0 \\
\hline D11 & $(1,1,1)$ & $\mathrm{Y}_{\mathrm{t}}=-0.368-0.507 \mathrm{Y}_{\mathrm{t}-1}+0.985 \varepsilon_{\mathrm{t}-1}+\varepsilon_{\mathrm{t}}$ & 0 & 1 \\
\hline D12 & $(1,1,1)$ & $\mathrm{Y}_{\mathrm{t}}=-0.672-0.447 \mathrm{Y}_{\mathrm{t}-1}+0.997 \varepsilon_{\mathrm{t}-1}+\varepsilon_{\mathrm{t}}$ & 1 & 0 \\
\hline D13 & $(1,1,1)$ & $\mathrm{Y}_{\mathrm{t}}=-0.364-0.579 \mathrm{Y}_{\mathrm{t}-1}+0.994 \varepsilon_{\mathrm{t}-1}+\varepsilon_{\mathrm{t}}$ & 0 & 1 \\
\hline D14 & $(1,1,2)$ & $\mathrm{Y}_{\mathrm{t}}=-0.434-0.614 \mathrm{Y}_{\mathrm{t}-1}+1.042 \varepsilon_{\mathrm{t}-1}+0.055 \varepsilon_{\mathrm{t}-2}+\varepsilon_{\mathrm{t}}$ & 0 & 1 \\
\hline D15 & $(2,1,1)$ & $\mathrm{Y}_{\mathrm{t}}=-0.350-0.649 \mathrm{Y}_{\mathrm{t}-1}-0.239 \mathrm{Y}_{\mathrm{t}-2}+0.985 \varepsilon_{\mathrm{t}-1}+\varepsilon_{\mathrm{t}}$ & 3 & 4 \\
\hline D16 & $(1,1,1)$ & $Y_{t}=-0.835-0.505 Y_{t-1}+0.992 \varepsilon_{t-1}+\varepsilon_{t}$ & 2 & 0 \\
\hline D17 & $(1,1,2)$ & $\mathrm{Y}_{\mathrm{t}}=-0.399-0.645 \mathrm{Y}_{\mathrm{t}-1}-0.980 \varepsilon_{\mathrm{t}-1}+0.007 \varepsilon_{\mathrm{t}-2}+\varepsilon_{\mathrm{t}}$ & 0 & 1 \\
\hline D18 & $(1,1,1)$ & $\mathrm{Y}_{\mathrm{t}}=-0.247-0.587 \mathrm{Y}_{\mathrm{t}-1}+0.987 \varepsilon_{\mathrm{t}-1}+\varepsilon_{\mathrm{t}}$ & 2 & 3 \\
\hline D19 & $(1,1,1)$ & $\mathrm{Y}_{\mathrm{t}}=-0.945-0.578 \mathrm{Y}_{\mathrm{t}-1}+0.993 \varepsilon_{\mathrm{t}-1}+\varepsilon_{\mathrm{t}}$ & 2 & 0 \\
\hline D20 & $(1,1,1)$ & $\mathrm{Y}_{\mathrm{t}}=-0.350-0.566 \mathrm{Y}_{\mathrm{t}-1}+0.998 \varepsilon_{\mathrm{t}-1}+\varepsilon_{\mathrm{t}}$ & 2 & 2 \\
\hline D21 & $(1,1,1)$ & $Y_{t}=-0.225-0.461 Y_{t-1}+0.997 \varepsilon_{t-1}+\varepsilon_{t}$ & 0 & 0 \\
\hline D22 & $(1,1,1)$ & $\mathrm{Y}_{\mathrm{t}}=-0.489-0.530 \mathrm{Y}_{\mathrm{t}-1}+0.993 \varepsilon_{\mathrm{t}-1}+\varepsilon_{\mathrm{t}}$ & 2 & 0 \\
\hline D23 & $(1,1,2)$ & $\mathrm{Y}_{\mathrm{t}}=-0.280-0.681 \mathrm{Y}_{\mathrm{t}-1}+0.958 \varepsilon_{\mathrm{t}-1}+0.029 \varepsilon_{\mathrm{t}-2}+\varepsilon_{\mathrm{t}}$ & 0 & 0 \\
\hline D24 & $(1,1,1)$ & $\mathrm{Y}_{\mathrm{t}}=-0.204-0.520 \mathrm{Y}_{\mathrm{t}-1}+0.997 \varepsilon_{\mathrm{t}-1}+\varepsilon_{\mathrm{t}}$ & 0 & 0 \\
\hline D25 & $(1,1,1)$ & $\mathrm{Y}_{\mathrm{t}}=-0.479-0.520 \mathrm{Y}_{\mathrm{t}-1}+0.997 \varepsilon_{\mathrm{t}-1}+\varepsilon_{\mathrm{t}}$ & 0 & 1 \\
\hline D26 & $(1,1,2)$ & $\mathrm{Y}_{\mathrm{t}}=-0.360-0.674 \mathrm{Y}_{\mathrm{t}-1}+0.925 \varepsilon_{\mathrm{t}-1}+0.064 \varepsilon_{\mathrm{t}-2}+\varepsilon_{\mathrm{t}}$ & 0 & 1 \\
\hline D27 & $(1,1,1)$ & $\mathrm{Y}_{\mathrm{t}}=-0.248-0.373 \mathrm{Y}_{\mathrm{t}-1}+0.983 \varepsilon_{\mathrm{t}-1}+\varepsilon_{\mathrm{t}}$ & 0 & 0 \\
\hline D28 & $(1,1,1)$ & $Y_{t}=-0.347-0.565 Y_{t-1}+0.986 \varepsilon_{t-1}+\varepsilon_{t}$ & 0 & 1 \\
\hline D29 & $(1,1,2)$ & $\mathrm{Y}_{\mathrm{t}}=-0.328-0.667 \mathrm{Y}_{\mathrm{t}-1}+0.983 \varepsilon_{\mathrm{t}-1}+0.003 \varepsilon_{\mathrm{t}-2}+\varepsilon_{\mathrm{t}}$ & 0 & 1 \\
\hline D30 & $(2,1,1)$ & $\mathrm{Y}_{\mathrm{t}}=0.105-0.524 \mathrm{Y}_{\mathrm{t}-1}+0.482 \mathrm{Y}_{\mathrm{t}-2}+0.888 \varepsilon_{\mathrm{t}-1}+0.096 \varepsilon_{\mathrm{t}-2}+\varepsilon_{\mathrm{t}}$ & 0 & 0 \\
\hline
\end{tabular}




\section{ANALISIS SEMIVARIOGRAM EKSPERIMENTAL}

Kriging bertujuan melakukan interpolasi optimal berdasarkan pada prinsip regresi dan nilai-nilai observasi disekitarnya, dengan melibatkan kovariansi dan korelasi spasial. Proses awal dalam Kriging adalah memodelkan kebergantungan spasial dan semivariogramnya. Analisis semivariogram memberikan informasi terkait karakteristik kebergantungan dari observasi yang ada. Analisis geostatistika menyediakan beberapa pilihan model semivariogram dan parameternya. Pemilihan semivariogram yang tepat berpengaruh pada pemodelan spasial yang akurat. Pemilihan semivariogram sebaran jumlah ulat api Blok Afdeling-D dilakukan dengan menentukan semivariogram $(\gamma(h))$ arah vertikal, horizontal dan diagonal [4].

$$
\gamma(h)=\frac{1}{2|N(h)|} \sum_{\left(s_{i}, s_{j}\right)}\left(Z\left(s_{i}\right)-Z\left(s_{j}\right)\right)^{2}
$$

dengan $N$ merupakan jumlah lokasi sejauh $h, Z(s)$ jumlah ulat api pada lokasi $s$. Berdasarkan semivariogram yang diperoleh, dilakukan fitting model semivariogram dengan model variogram yang ada. Model variogram yang sering dipakai adalah Sperikal, Gaussian dan Eksponensial, dengan $a$ adalah range menuju sill, $h$ merupakan jarak antar lokasi observasi dan $C$ adalah sill, merupakan variansi dari sampel data [4].

a. Sperikal

$$
\begin{aligned}
& \mathrm{G}(h)=\left((3 / 2)(h / a)-(1 / 2)(h / a)^{3}\right) \text { untuk } 0<\mathrm{h}<a \\
& \mathrm{G}(h)=1 \text { untuk } h \geq a
\end{aligned}
$$

b. Gaussian

$$
\left.\mathrm{G}(h)=1-\exp (h / a)^{2}\right)
$$

c. Eksponensial

$$
\mathrm{G}(h)=1-\exp (h / a))
$$

Berikut ini merupakan hasil pemodelan semivariogram dan variogram pada hasil forecasting ARIMA jumlah ulat api pada Blok Afdeling D untuk forecasting 1 dan 2,

I. Variogram Forecasting 1

Berikut ini merupakan calon model variogram untuk forecasting 1 ,

a. Sperikal

$\mathrm{G}(x)=0.8092\left((3 / 2)(x / 4.345)-(1 / 2)(x / 4.345)^{3}\right)$ untuk $x \geq 4.345$

$\mathrm{G}(x)=0.8092$ untuk $x>4.345$

b. Gaussian

$\mathrm{G}(x)=0.8092\left(1-\exp (x / 0.872)^{2}\right)$

c. Ekponensial

$\mathrm{G}(x)=0.8092(1-\exp (x / 0.872))$
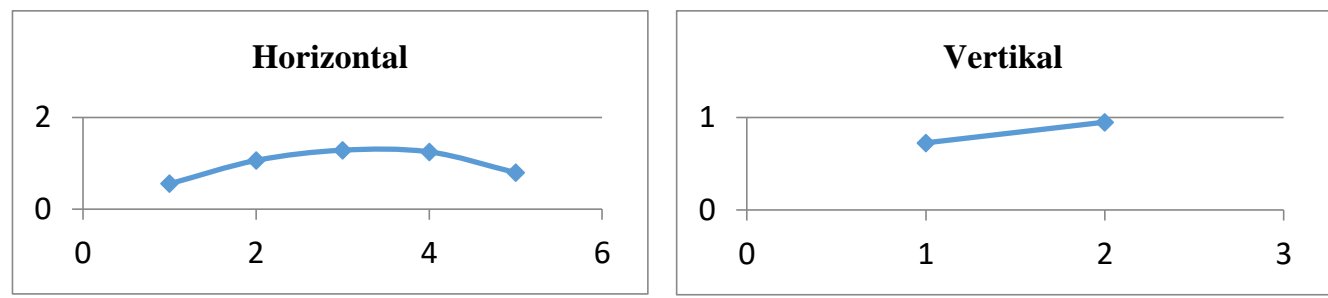

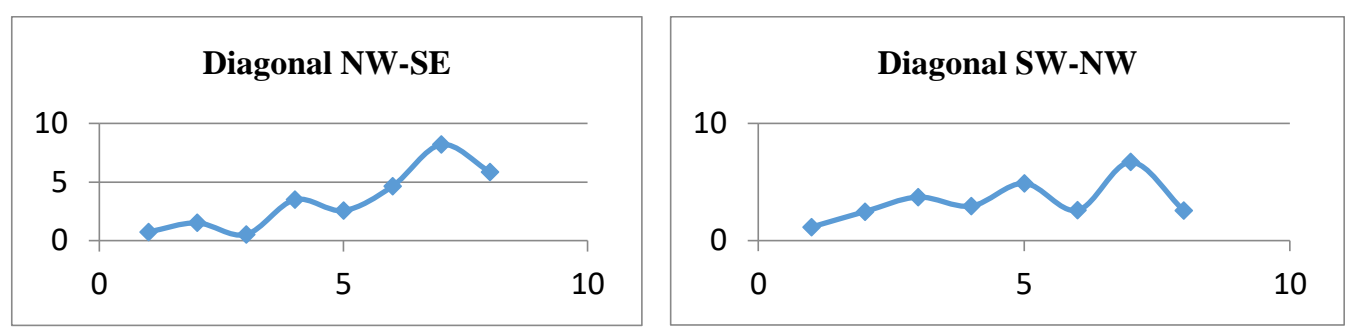

GAMBAR 6. SEMIVARIOGRAM VERTIKAL, HORIZONTAL DAN DIAGONAL FORECASTING 1

Pada Gambar 6 merupakan hasil semivariogram eksprimental arah vertikal, horizontal dan diagonal positif - negatif berdasarkan sebaran lokasi dan jumlah ulat api forecasting 1. Selanjutnya, dilakukan fitting semivariogram dengan variogram Sperikal, Gausian, dan Eksponensial. dengan mempertimbangkan nilai Mean Square Error (MSE) terkecil pada Tabel 3,

TABEL 2. MSE VARIOGRAM FORECASTING 1

\begin{tabular}{|l|c|c|c|}
\hline & Sperikal & Gaussian & Eksponensial \\
\hline MSE & 108.129 & 106.233 & 106.274 \\
\hline
\end{tabular}

II. Variogram Forecasting 2

Berikut ini merupakan calon model variogram untuk forecasting 2,

a. Sperikal

$$
\begin{aligned}
& \mathrm{G}(x)=0.9195\left((3 / 2)(x / 3.966)-(1 / 2)(x / 3.966)^{3}\right) \text { untuk } x \geq 3.966 \\
& \mathrm{G}(x)=0.9195 \text { untuk } x>3.966
\end{aligned}
$$

b. Gaussian

$\mathrm{G}(x)=0.9195\left(1-\exp (x / 0.774)^{2}\right)$

c. Ekponensial

$$
\mathrm{G}(x)=0.9195(1-\exp (x / 0.334))
$$

Hasil semivariogram eksperimental untuk arah vertikal, horisontal dan digonal postif-negatif pada forecasting 2 dapat dilihat pada Gambar 7. Empat semivariogram memiliki karakteristik isotropik, yaitu kemiripan semivariogram dengan kecenderungan tren naik

\section{TABEL 3. MSE VARIOGRAM FORECASTING 2}

\begin{tabular}{|l|c|c|c|}
\hline & Sperikal & Gaussian & Eksponensial \\
\hline MSE & 85.643 & 82.445 & 106.274 \\
\hline
\end{tabular}
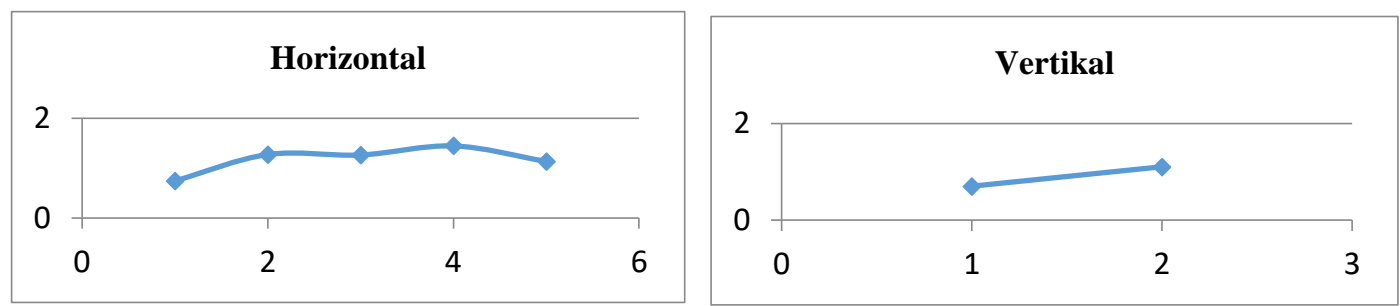

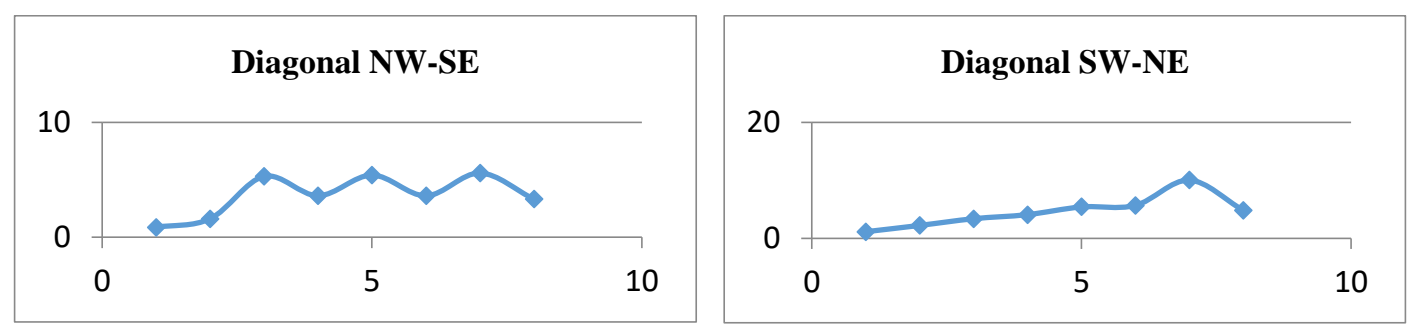

GAMBAR 7. SEMIVARIOGRAM VERTIKAL, HORIZONTAL, DIAGONAL FORECASTING 2

Berdasarkan semivariogram yang isotropik dari forecasting 1 dan 2, selanjutnya dilakukan fitting untuk menentukan model variogram yang sesuai. Fitting semivariogram dengan model variogram Sperikal, Gausian, dan Eksponensial diilakukan dengan mempertimbangkan nilai MSE terkecil pada semivariogram Tabel 2 dan 3.

Misalkan terdapat $n$ data spasial $\mathrm{Z}\left(\mathrm{s}_{1}\right), \mathrm{Z}\left(\mathrm{s}_{2}\right), \ldots, \mathrm{Z}\left(\mathrm{s}_{\mathrm{n}}\right)$, lokasi baru $\mathrm{Z}_{\mathrm{V}}$ dengan dapat diestimasi dengan persamaan Kriging,

$$
\widehat{Z_{V}}=\mu+\sum_{i=1}^{n} \lambda_{i} Z\left(s_{i}\right)
$$

dengan $\lambda_{i}$ merupakan bobot lokasi $i, i=1,2, \ldots, n$. Pemilihan bobot haruslah tak bias dengan $E\left(\widehat{Z_{V}}-Z_{V}\right)=0$ dan meminimunkan $\operatorname{Var}\left(\widehat{Z_{V}}-Z_{V}\right)$. Penentuan bobot optimal $\lambda_{i}$ dilakukan dengan Lagrange Multiplier, sehingga diperoleh persamaan,

$$
\sum_{i=1}^{n} \lambda_{i} \gamma\left(s_{i}, s_{j}\right)+m=\gamma\left(s_{i}, V\right)
$$

dengan $\sum_{i} \lambda_{i}=1$. Nilai $\gamma\left(s_{i}, s_{j}\right)$ diaproksimasi dari semivariogram (1) dan $m$ merupakan aproksimasi $\mu$ yaitu mean dari observasi, $E(Z)$. Berdasarkan (4) dan (5) dilakukan interpolasi dua lokasi baru Ulat Api.

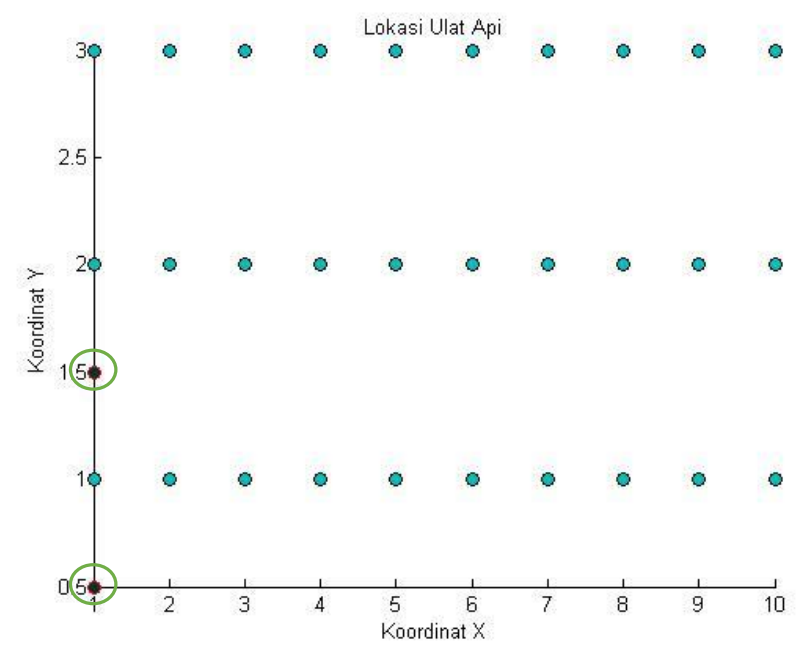

GAMBAR 8. INTERPOLASI LOKASI BARU (MERAH) ULAT API 
Semivariogram, Gambar 7 dan 8, menunjukkan hasil isotropik, sehingga berdasarkan hasil MSE Tabel 3 dan 4, maka MSE terkecil diperoleh dari variogram Gaussian. Interpolasi Kriging (4) dan (5) dilakukan dengan melibatkan model variogram Gaussian dari forecasting 1 dan 2. Hasil interpolasi Kriging, Gambar 8, merupakan lokasi baru migrasi Ulat Api pada Blok Afdeling D.

\section{KESIMPULAN}

Jumlah sebaran ulat ini memiliki kemiripan pada setiap Blok Afdeling-D periode Januari 2011 - Desember 2013. Ulat Api menyebar secara musiman pada seluruh blok, baik blok yang berdekatan maupun berjauhan. Sebaran scatterplot Ulat Api memiliki karakteristik seasonal time series dan spasial, yang ditunjukkan oleh nilai korelasi Pearson $(\rho)$ antara 0.78 sampai 0.96 pada setiap blok. Tujuan utama analisis spasial time series adalah memodelkan mekanisme stokastik dari observasi yang dikumpulkan berdasarkan runtun waktu dan lokasi untuk memprediksi lokasi dan jumlah ulat api periode selanjutnya. Berdasarkan nilai mean error terkecil diperoleh model time series ARIMA sebagai model time series untuk memprediksi jumlah Ulat Api periode berikutnya. Hasil interpolasi dan menunjukkan tren sebaran lokasi Ulat Api tidak dipengaruhi oleh jarak antar blok. Pembasmian hama Ulat Api harus dilakukan serentak untuk menghindari migrasi Ulat Api ke blok sekitarnya. Model variogram yang sesuai berdasarkan semivariogram eksperimental adalah Gaussian dengan nilai MSE terkecil 1.06\%. Interpolasi Kriging, menunjukkan bahwa lokasi interpolasi yang baru memiliki kemiripan jumlah Ulat Api dengan lokasi disekitarnya.

\section{UCAPAN TERIMA KASIH}

Untuk seluruh pihak yang telah membantu penyelesaian penelitian ini: Dr. Utriweni Mukhaiyar atas informasi data yang diberikan.

\section{DAFTAR PUSTAKA}

[1] Dinas Perkebunan Provinsi Kalimantan. 2011. Ulat Api Kelapa Sawit.

[2] Bohling, G. 2005. Kriging. Kansas Geological Survey.

[3] Amstrong, M.. 1998. Basic Linear Geostatistic. Berlin : Springer - Verlag.

[4] Cryer, J.D., Chan, K.S. 2008. Time Series Analysis with Application in R. Second Edition. Springer.

[5] Kyriakidis C., Journel A. 2001. Stochastic modeling of atmospheric pollution: a spatial time-series framework. Part I: methodology. Atmospheric Environment, pp 2331-2337. Elsevier

[6] Zhou, M., \& Buongiorno, J. 2006. Space-time modeling of timber prices. Journal of Agricultural and Resource Economics, 40-56.

[7] Zhang, Pusheng, et al. 2003. Correlation analysis of spatial time series datasets: A filter-and-refine approach. In: Pacific-Asia Conference on Knowledge Discovery and Data Mining. Springer Berlin Heidelberg. p. 532-544.

[8[ Arbia G., et al. 2014. A Micro Spatial Analysis of Firm Demography of Food Stores in The Area of Trento. Springer 